\title{
HARNESSING PRODUCTION NETWORKS
}


The Institute of Southeast Asian Studies (ISEAS) was established as an autonomous organization in 1968. It is a regional centre dedicated to the study of socio-political, security and economic trends and developments in Southeast Asia and its wider geostrategic and economic environment.

The Institute's research programmes are the Regional Economic Studies (RES, including ASEAN and APEC), Regional Strategic and Political Studies (RSPS), and Regional Social and Cultural Studies (RSCS).

ISEAS Publications, an established academic press, has issued more than 2,000 books and journals. It is the largest scholarly publisher of research about Southeast Asia from within the region. ISEAS Publications works with many other academic and trade publishers and distributors to disseminate important research and analyses from and about Southeast Asia to the rest of the world. 


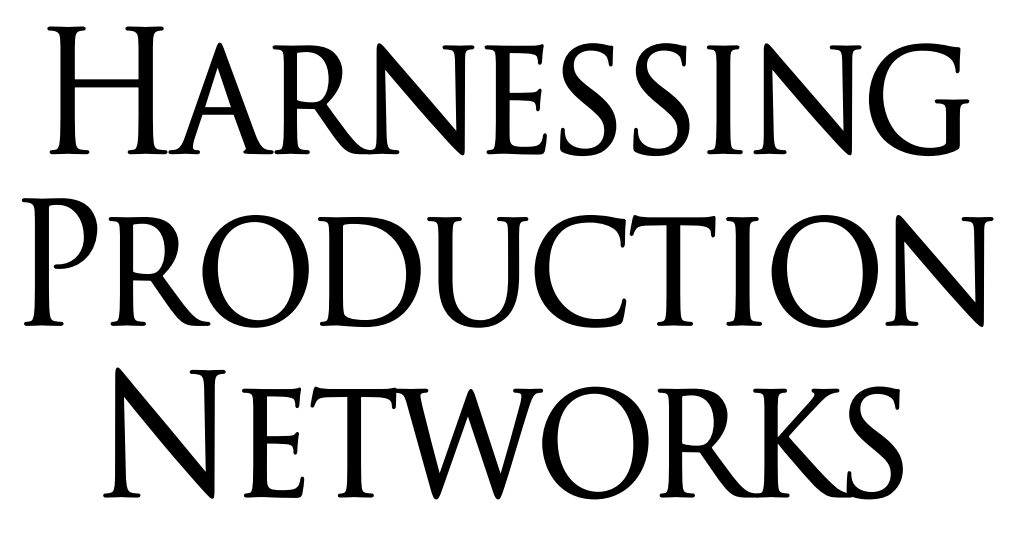

Impacts and Policy

Implications from Thailand's

Manufacturing Industries

AEKAPOL CHONGVILAIVAN

느리느

INSTITUTE OF SOUTHEAST ASIAN STUDIES

Singapore 
First published in Singapore in 2011 by ISEAS Publishing

Institute of Southeast Asian Studies

30 Heng Mui Keng Terrace

Pasir Panjang

Singapore 119614

E-mail: publish@iseas.edu.sg

Website: http://bookshop.iseas.edu.sg

All rights reserved. No part of this publication may be reproduced, stored in a retrieval system, or transmitted in any form or by any means, electronic, mechanical, photocopying, recording or otherwise, without the prior permission of the Institute of Southeast Asian Studies.

(C) 2011 Institute of Southeast Asian Studies, Singapore

The responsibility for facts and opinions in this publication rests exclusively with the author and his interpretations do not necessarily reflect the views or the policy of the publisher or its supporters.

\section{ISEAS Library Cataloguing-in-Publication Data}

Aekapol Chongvilaivan.

Harnessing production networks : impacts and policy implications from

Thailand's manufacturing industries.

1. Manufacturing industries-Thailand.

2. Industrial productivity-Thailand.

3. Labour productivity-Thailand.

4. Skilled labour-Thailand.

5. Contracting out-Thailand.

I. Title.

HD9736 T42A24 2011

ISBN 978-981-4311-26-7 (soft cover)

ISBN 978-981-4311-27-4 (E-book PDF)

Typeset by International Typesetters Pte Ltd

Printed in Singapore by Markano Print Media Pte Ltd 